\title{
The Implementation For The Seeker Confidence After The Enactment Of The Constitutional Court Decision No. 97/Puu-Xiv / 2016 Concerning Population Administration In Rembang District
}

\author{
Denni Saputra ${ }^{1}$; Akhmad Khisni ${ }^{2}$ and Munsyarif Abdul Chalim ${ }^{3}$
}

Abstract. Problems of this research is how the implementation for the seeker of confidence after the enactment of the Constitutional Court decision No. 97 / PUUXIV / 2016 concerning Population Administration; how the implementation of the marriage for the seeker of trust; how the solution implementation barriers for seeker confidence of marital trust; how the notary authority in making authentic act for marriage seeker of confidence. The method used in this research is empirical juridical approach derived from data obtained from the collection of primary data and secondary data, and then analysed by qualitative descriptive analysis method. The data collection technique used was the study of literature (laws, and books about this research) and field studies (interviews with respondents who made sources). Data analysis technique using qualitative data analysis.

Based on the findings of researchers showed that appear false assumption of the seeker of the belief that the implementation of the marriage for the seeker of trust cannot be empowered by law, cannot be served their implementation by the competent authority; The absence of laws that specifically regulate: the Marriage of the seeker, recognition that the seeker of trust including one of the official religion; providing solutions to create and revise laws pertaining to the seeker of such beliefs in terms of recognition as a religion and the administration of residence; Notary involves authority until now could not be done on the implementation of the marriage for the seeker of Faith, a notary has no authority in making authentic act, in the absence of legislation governing it. But it can be circumvented by issuing a certificate in Partij deed.

Keywords: Marriage; Seeker Confidence; Population Administration.

\section{Introduction}

Indonesia is a country made up of thousands of islands and varied ethnicities. So is religion and beliefs held by each of the ethnic groups. However, despite the diverse ethnic and religious backgrounds, but the people of Indonesia remains one, this is in accordance with the philosophy of the Indonesian nation, which is Unity in Diversity.

Diverse array identity of the Indonesian population, leading to the rule of law be diverse as well. One of them is the setting of the marriage or wedding. Legitimacy of marriage under Indonesian law as stipulated in Act No. 1 of 1974 is valid according to religion and legitimate by the state. If religion prospective husband and wife candidate is a government-recognized religion is not an issue. However, what if 'religion' were adopted is the flow of Faith against God Almighty? Meanwhile, in the determination of the president No. 1 of 1965 cult, is not listed as a religion recognized by the government.

In that we all have to realize that the relationship between law, politics, and bureaucracy is constructed by people as a reciprocal and dynamic relationship.

\footnotetext{
${ }^{1}$ Students Master of Notary Law, Unissula email: denni.saputra30@gmail.com

2 Lecturer of Faculty of Law Unissula

3 Ibid.
} 
Dynamic society have an impact on the importance of customization and / or the passing of new legislation. The substance of the actual law is lack of certainty of bureaucracy and requirements of the central government, local government, the public and private sectors (governance) in order to achieve national development goals. ${ }^{4}$

The dynamics that determine the construction of priority between the laws should take precedence or bureaucracy precedence. The relation of both culminate in the debate between the egg and the chicken. Law creates bureaucracy via political, or bureaucratic produce legal products via politics? Bureaucracy can run with the legitimacy of the law governing the nomenclature, governance, promotion and sanctions, human resource development, monitoring and assessment, funding and accountability mechanisms. Because the bureaucracy is essentially to provide excellent service to users within their authority.

When the organizers of the bureaucracy froze and / or a legal vacuum, it absolutely must be done breakthrough or discretion. The logic of the current law is a legal vacuum should be produced laws that guarantee the organization of the bureaucracy, especially the certainty of public service delivery. In relation to cross chaos marriage documentation for seeker confidence has actually been a decision of the Constitutional Court Number 97 / PUU-XIV / 2016 about a lawsuit against Act No. 23 of 2006 and Act No. 24 Year 2013 concerning Population Administration, which can be used as a reference the problem of registration of marriages for the seeker of cult. But on the other hand legal product also is the work of the legislative body, so it is very susceptible to politicization of law.

This issue was time to find a way out especially by the Notary considering they spearhead an authentic deed making authority on all deeds, agreements, and determination required by legislation. So the idea, the thought, the idea of the Notary is very important to be explored.

Based on the background of these problems, the authors are interested in doing research thesis under the title "Implementation of Confidence after Marriage For seeker confidence Applicability Constitutional Court Decision Number 97 / PUU-XIV / 2016 About the Population Administration in Rembang".

Based on description in the above background, it is an issue of concern in this study is how the implementation of the marriage for the seeker of confidence after the enactment of the Constitutional Court decision No. 97 / PUU-XIV / 2016 concerning Population Administration?, What barriers to implementation seeker confidence marital trust?, what solution implementation barriers for seeker confidence marital trust?, How Notary authority in making authentic act for marriage seeker confidence?

\section{Research methods}

The method used in this research is empirical juridical approach or the so-called well with empirical normative. Judicial approach used to analyse a wide range of legislation in the field of law relating to the implementation of the marriage for the seeker of confidence. While empirical approach carried out to analyse the law as a social phenomenon or behaviour in public life who always integrate a continuous basis or in relation to aspects of community life. This research is descriptive analysis that aims to

${ }^{4}$ Abd. Latif Bustami, 2-5 Oktober 2016, Peraturan Perundang-undangan bidang kepercayaan Terhadap Tuhan Yang Maha Esa, https://kebudayaan.kemdikbud.go.id/ditkt/wpcontent/uploads/sites/6/2016/11/Makalah-Peraturan-Perundang-Undangan-Bidang-

Kepercayaan-Terhadap-Tuhan-Yang-Maha-Esa-dan-Tradisi.pdf, Retrieved on Saturday, 23-022019 , at $14: 18 \mathrm{pm}$ 
measure carefully and give a description of the symptoms that are at issue to be discussed. The data collection technique used was the study of literature (laws, and books about this research) and field studies (interviews with respondents who made sources). Data analysis technique using qualitative data analysis, and then arranged in a systematic order to obtain clarity on the issue and then conclude deductively.

\section{Results and Discussion}

\subsection{Implementation of the marriage for the seeker of confidence after the enactment of the Constitutional Court decision No. 97 / PUU-XIV / 2016 concerning Population Administration}

In the beginning of the study authors journey to meet Mr. Suyono. From it the author get the story how complicated the trust of Hayuningrat seeker must be willing to choose one of the officially recognized religions in order to obtain the validity of these difficulties encountered when marrying his daughter.

"If the first process is difficult, my son got married in 2015 at KUA. The process is still very complicated ID cards are still very difficult. But later when the affairs of completion, will I replace".

Things are somewhat different happens to the informer Bambang Triyono he actually managed to register the marriage in the Civil Registry Office, first performed in front of religious leaders after that were listed in the registry office of the interviews 2 (two) informant above if we look at the holding of marriage may the same that 2015 will be different but the process is the daughter of Mr. Suyono must marry a Muslim while Mr. Bambang Triyono can marry as beliefs. It happened because the informant was staying in a different area in the village while Mr. Suyono Mr Bambang Triyono are in town why living in the city do not meet the constraints? While the recognition of Mr Suyono: "Just for ID Card process to the district I must go back and forth six times whereas in other areas have been willing to change the religion column but here do not want fearing father scolded by village heads"

This would mean that the knowledge of the village also became one of the factors that affect the difficulty of a seeker easy to get service. "There should be a socialization in the form of seminars in areas that government agencies both central to the area knowing that it has no rules regarding the administration of residence and rights in terms of relations and legal status equal to nationals or people of other faiths, so that one sound when there are cases in the area in order to provide service to the people" Thus the opinion of a Notary in Rembang, Mr Muchamad Al Hilal when asked about the uniformity of services provided by government agencies in the region to the seeker of confidence.

Ideally, after the enactment of the Constitutional Court decision No. 97 / PUU-XIV / 2016 on Lawsuit Article 61 (1) and (2) of Act No. 23 of 2006 concerning Population Administration in conjunction with Article 64 paragraph (1) and (5) of Act No. 24 of 2013 on the Amendment of Act No. 23 of 2006, the government should aggressively charging socialization of their religion column for the seeker in the electronic ID card in order to give legitimacy lawfully given to the adherents seeker's confidence in conducting marriages. It is intended that the population administration achieved the better, especially in terms of registration of marriages for adherents seeker confidence Trust can provide legal certainty and legal deadlock does not occur in the community. But the main factor supporting the registration of marriages of the seeker of confidence in the Department of Population and Civil Registration of Rembang is the 
willingness of seeker confidence Trust for registered their marriages. Because there is also seeker confidence are still reluctant registered their marriages as happened to Mr. Dwi Karno. Despite his own understanding of the decision of this Court, he still let the marriage record that still use the recording in Islam. "Yes brother in ID Card still stated Islam...so I'm still let it on"

If viewed in terms of time, registration of marriage to the seeker of trust with the passing of PP 37 in 2007 is divided into two types, namely the registration of marriages are conducted in confidence after the adoption of Regulation No. 37 in 2007 and the registration of marriages to marriages performed before the PP 37 in 2007. From research conducted at the Department of Population and Civil Registration of Rembang, registration of marriages to marriages conducted in confidence after the adoption of Regulation No. 37 of 2007 has been running effectively. It can be seen from the 3 (three) indicators used application for registration of marriage to the Department of Population and Civil Registration. In Rembang itself after the adoption of Regulation No. 37 In 2007 there were four reports seeker confidence registration of marriages in the period 2009-2015.

Table 3 Reports Seeker Confidence Faith Marriage Registration

\begin{tabular}{|c|l|l|l|c|}
\hline $\begin{array}{c}\text { No } \\
.\end{array}$ & \multicolumn{1}{|c|}{ Couple name } & \multicolumn{1}{|c|}{ Address } & \multicolumn{1}{|c|}{$\begin{array}{c}\text { Seeker } \\
\text { confidence }\end{array}$} & Year \\
\hline 1 & Suwarno-Wahyuni & $\begin{array}{l}\text { Sendang Mulyo } \\
\text { Village, Dist. Bulu }\end{array}$ & $\begin{array}{l}\text { Palang Putih } \\
\text { Nusantara }\end{array}$ & 2009 \\
\hline 2 & $\begin{array}{l}\text { Bambang Triyono- } \\
\text { Septiyan Kusrini }\end{array}$ & $\begin{array}{l}\text { District of Pacar, } \\
\text { Rembang }\end{array}$ & Sapta Darma & 2014 \\
\hline 3 & $\begin{array}{l}\text { Susanto-Suntari } \\
4\end{array}$ & $\begin{array}{l}\text { Tasikharjo Village, } \\
\text { Dist. Kaliori }\end{array}$ & Sapta Darma & 2015 \\
\hline $\begin{array}{l}\text { Dutra-Nimas Bindhu } \\
\text { Puspaningtyas Dwi } \\
\text { Werdati }\end{array}$ & $\begin{array}{l}\text { Sumberjo Village, } \\
\text { Dist.Rembang }\end{array}$ & Sapta Darma & 2015 \\
\hline
\end{tabular}

\subsection{Barriers to implementation of marriages for seeker confidence}

The absence of legal certainty which is obtained by the seeker of trust makes the seeker of trust pessimistic in the face of bureaucracy in the relevant institutions, for example in terms of performing the marriage of the seeker are still many who are forced to recognize other religions as his religion for the sake of marriage can be called legitimate, recognized by the state and listed. This situation is aggravated by the public perception that evaluated the implementation of marriages for the seeker of trust is something unusual in the midst of society. But the fact that this flow of life among the people and it is difficult for forbidden only needs accommodated as the cultural treasures of our country" as an expression of DR. H. Wira Franciska, SH., MH.

Other barriers regarding registration of marriages of the seeker of trust executed before their PP 37 in 2007 and the Decision of the Constitutional Court No. 97 / PUUXIV / 2016 is the absence of a request from the people who will register marriages to the Department of Population and Civil Registration of Rembang. From interviews with the Head of the Section of Marriage of Rembang, Mr Salim, S.Sos during the period given by the Government in the PP 37 in 2007, ie between the years 2007-2008 even after the release of the Constitutional Court decision No. 97 / PUU-XIV / 2016 there is no longer a civil registry seeker confidence trust until now. This happens because of 
lack of willingness of seeker confidence to record the marriage has not been registered for reasons such as fear of negative stigma from society. "We are often called heresy ... or insane. So to be lazy when have to manage the letters which connected with birocration"

Once expression of Mr. Suyono when asked about the cause reluctance registered their marriages. Another cause is due to fear of not getting a good service from the local administration tools.

\subsection{Solution implementation barriers for seeker confidence marital}

Barriers that have been described above would have to be a solution found workarounds, in order not to place legal impasse. Because above all, superior service to society is the main objective. Steps and thought, no matter how small that simple and should still be pursued. Whether to establish a new law that specifically regulates the flow of confidence in Indonesia, or to standardize regulations implementing No. 9 1975 or by regulating the validity of the registration procedures for the implementation of the marriage seeker so many problems that had occurred can be overcome.

DR. Wira Franciska gives the opinion that "Due to legal sources in Indonesia is positive law which stem from the rules regarding Marriage Act, marriage while not yet entered the seeker of confidence in it, then the marriage is based on trust flow must be accommodated in it. How, by revising the Marriage Act or made a PP / Permen from the Ministry of Religion to be validated and recognized by the state."

Based on the above opinion, the authors assess the need for a pilot as he had done by Pastor Confucianism - WS Budi S Tanuwibowo - order services from the government for the trust to be completed seeker confidence way is to:

- Delivering a clear request to the government that there are solutions on the marriage for seeker confidence trust by basing on the idea that religion in Indonesia is not merely a private affair.

- Other efforts that can be done is to ask the government to seeker confidence Trust acceptable and endorsed the implementation of the marriage with the percentage seeker confidence consideration the substantial sums Trust community needs the legitimacy of the importance of marriage for the seeker of confidence that there is legal certainty. It could be a decree or separate legislation rules for the seeker of belief or confirmed in the Marriage Act No. 1 of 1974 through Implementation Regulation No. 9 of 1975.

Although the activities of registration of marriage was only administratively, but should not be ignored, because with the recording perpetrated by the civil registry can make an event of marriage becomes clearer and have legal certainty to the issuance of a marriage certificate or certificate is a proof of authenticity which describes a marriage has taken place.

\subsection{Notary authority in making authentic act for marriage seeker confidence}

One of the main authority is to make an authentic notary deed. What is an authentic act? Deed is an authentic deed made by or in the presence of a Notary according to the forms and procedures stipulated in this law (Article 1 paragraph 7 UUJN)

According to the certificate form can be divided into:

- Authentic deed is a deed made before and by the officials authorized to do so by the authorities, according to the provisions that have been set, either with or without the help of interested parties. 
- The deed is a deed under the hand that are made available for verification by the parties without the help of an official.

The biggest difference between the authentic act and deed under hand, are: ${ }^{5}$

- Authentic act has definite date, as stated in Article 15 paragraph (1) UUJN, while the deed under the hand does not always guarantee the certainty of the date;

- Grosse of the authentic act in some respects have the power executorial like the judge's ruling, while the deed under the hand does not have the power executorial;

Possibility of loss deed made under the hand is greater than the authentic deed.

The authentic act that created the Notary consists of two types, namely: ${ }^{6}$

- Relaas Deed or the Minutes is deed of Notary, the Notary deed is written or recorded all things seen or heard himself directly undertaken by the parties.

- Partij the deed or deed of the parties was a deed of Notary at the request of the parties, a notary is obliged to hear the statement or statements of the parties expressed or explained in person by Notary.

However, with regard to the authority of the Notary to create an authentic deed for the seeker of Faith DR. Wira Franciska says: " Still Can't be implemented execution are recorded and made marriage a marriage certificate for the seeker confidence in notary because there has been no legislation governing the implementation of the marriage for the seeker of confidence in spite of the PP No. 37 of 2007".

It happened because there has been no in-depth explanation of the rules of marriage seeker confidence Trust. There is only regulated procedures for the implementation of the course, a notary can not necessarily make their marriage certificate for seeker confidence Trust.

However, based on Notarial statement Muchamad Al Hilal: "Throughout the implementation of the marriage has been registered at the relevant office in this case the Department of Population and Civil Registration, the rights of their civil be met by the rules of society in general by using the Book of Civil Law (Deed of Inheritance, buy, sell, lease, agreement Married, etc)."

This is corroborated by the opinion DR. Widhi Handoko: "Should be understood this way, the law that's not always normative, that the law was not it the goal to achieve justice, that if one country, I demonstrated the country's suppose rules, rules that aim, it must be addressed the principle of expediency. If the principle of benefit clash ensued then intended it to justice. So in the context of the values of justice it is called the law sometimes enforcement of law should do it ... for example, if some sort of Gustav say that no formal impasse. If marriage seeker could have said the deadlock cannot. Why do I call no deadlock? Because in fact there's been a decision that could be a reference. Well that just made the decision as a reference, is not so. Now the question is whether the decision was still no obstructions present example, the applicable law that legitimizes the religion column in the ID card. That's not cause real problems, when we follow the decision, since the decision had nothing to do with the law but when we are referring to Act No. 10 of 2004 then we are also referring to Act No. 12 of 2011 the actual legal position that's already clearly regulated. What makes the problem that human beings themselves. Wong legal standing right there is no problem. Law kan higher than regulation. It's a technical matter can also be made by internal technical as long as it does not violate the law right so ... "

\footnotetext{
${ }^{5}$ G.H.S. Lumban Tobing, 1983, Peraturan Jabatan Notaris, Erlangga, Jakarta, p. 54

6 Habib Adjie, SH., M.Hum, 2008, Hukum Notaris Indonesia Tafsir Tematik Terhadap UU No. 30

Tahun 2004 Tentang Jabatan Notaris, PT. Refika Aditama, Bandung, p. 45
} 
When asked further about the role of the Notary in authority to make the authentic act, he replied: "Partij deed or not it has been described actual relaas're not limit could eventually be handled everything. If we want to talk about the authority we know what ... Notary's authority, he was to make the deed or relaas Partij deed, when we talk letter is not assigned by a Notary, the Notary assigned birth suppose on my question whether the Notary may make the birth certificate? May. Here's the birth certificate that's created by ie. civil records, civil records to explain right in the birth certificate, right? Well, my question, if the information is born right Notary hear the parties provide information and Notary explained based on the testimony of the parties. That is no problem right here... it means what? This means that when a person is explained in Partij deed, should not it should no longer be questioned. "

Therefore parse the question of marriage for the seeker of trust should observe the principle of expediency and the most important is the principle of justice. When they want to enter into marriage should not be complicated simply because of religion or belief which is not acceptable by law. Therefore, the government needs to provide a way out directly from the upstream problems. In order of humanity and human rights, the bride can form a family and a valid marriage according to the laws in Indonesia, particularly in terms of civil law.

\section{Closing}

\subsection{Conclution}

After analyzing the research data and discussion, it can be concluded as follows:

- Effectiveness of the registration of marriages for seeker confidence trust governed by Act No. 23, 2006 that on Article 8, paragraph 4, which specifies that the obligation of recording important events for the seeker of confidence about the requirements and procedures for recording based on the legislation. Furthermore, to arrange a marriage for seeker confidence implementation of confidence that the PP 37 of 2007 on the implementation of Act No. 23 of 2006, contained in Article 81, which reads:

- Trust seeker marriage performed in the presence of leaders seeker confidence Trust.

- Leaders Trust seeker referred to in paragraph (1) appointed and confirmed by the organization seeker of trust, to fill out and sign a Trust seeker confidence marriage.

- Leaders Trust seeker referred to in paragraph (2) shall be registered in the areas of their ministry is technically foster seeker confidence organization Faith Against God Almighty.

- Lack of socialization PP 37 in 2007 and the Decision of the Constitutional Court No. 97 / PUU-XIV / 2016 to the seeker of confidence makes them not knowing that it administrative right of freedom to be seeker has been met by the state. This condition is compounded by a lack of understanding by employees of government agencies relating to look as though there is no legal certainty for the marriage of the seeker. The next logical consequence of the seeker of confidence to be pessimistic in the face of bureaucracy in the relevant institutions, for example in terms of performing the marriage of the seeker of confidence still many forced to recognize other religions as his religion for the sake of marriage can be called 
legitimate, recognized by the state and registered. Not to mention the stereotype in the community who think that the seeker of trust is a belief that is not uncommon.

- The solution of the above conditions is to socialize PP 37 In 2007, the Constitutional Court Decision No. 97 / PUU-XIV / 2016 and other laws and regulations relating to the seeker of confidence to the government agencies, communities, and seeker of the trust itself.

- Notary main authority is to make authentic act on all deeds, agreements and under what provisions are required by law and the parties desired. Thus Notary absolute authority by the legislation in force in Indonesia. In connection with the authority Notary until now could not be done on the implementation of the marriage for the seeker of Faith, a notary has no authority in making authentic act, in the absence of legislation governing it. But it can be circumvented by issuing a certificate in Partij deed.

\subsection{Suggestion}

- Must reformulate specific restrictions on the definition of religion and belief in the legislation, so it no longer avoid controversy and confusion of the meaning of the agencies and institutions relating directly or indirectly to the implementation of the marriage.

- Made laws or government regulations on the types of services for the seeker of trust associated with their presence in the midst of the community so there is no legal impasse.

- Given the percentage seeker of confidence in Rembang has a large amount then it is necessary for the government of Rembang so seeker confidence trust created to accommodate local regulations legal certainty for them.

- Notaries can make an authentic deed in the form Partij deed containing the wishes and will of the parties in accordance with the provisions of Notary Law for seeker confidence trust.

\section{Bibliography}

[1] G.H.S. Lumban Tobing, 1983, Peraturan Jabatan Notaris, Erlangga, Jakarta.

[2] Habib Adjie, SH., M.Hum, 2008, Hukum Notaris Indonesia Tafsir Tematik Terhadap UU No. 30 Tahun 2004 Tentang Jabatan Notaris, PT. Refika Aditama, Bandung.

[3] Abd. Latif Bustami, 2-5 Oktober 2016, Peraturan Perundang-undangan bidang kepercayaan Terhadap Tuhan Mang Maha https://kebudayaan.kemdikbud.go.id/ditkt/wpcontent/uploads/sites/6/2016/11/Makalah-Peraturan-Perundang-UndanganBidang-Kepercayaan-Terhadap-Tuhan-Yang-Maha-Esa-dan-Tradisi.pdf, Accessed on Saturday, 23-02-2019, at 14:18 pm 